Nesse artigo a arte-educação será entendida como uma intervenção ativa no desenvolvimento cultural da comunidade, através do estudo dos usos passados e presentes da arte africana como veículo para a manutenção do controle social, para o desenvolvimento de conceitos históricos, e como disseminadora de valores educacionais. Discutiremos primeiramente alguns exemplos de arte africana em sociedades tradicionais como ferramentas para controle social, memória histórica e educação e depois discutiremos de que modo conceitos similares são manifestados nas sociedades urbanas contemporâneas, com ênfase no movimento set-setal que ocorreu no Senegal entre os anos de 1989 e 1992.

Palavras-chave: comunidade, arte-educação, arte africana. 


\section{Art education serves the community: an historic view of African and the Diaspora}

Jacqueline

CHANDA

abstract

This paper will look at art education as an active intervention in community cultural development by looking briefly at past and present uses of African art as vehicles for maintaining social control, developing historical concepts, and disseminating educational values. We will first discuss some examples of African art objects in traditional societies as tools for social control, historic memory and education and then discuss how similar concepts are manifest in contemporary urban societies by looking a more contemporary example in the form of a phenomenon called set-setal, a movement that took place in Senegal between the years of 1989 and 1992. Key-words: community, art education, african art. 
Community art education has become a hot topic in recent years. In the context of America, it is generally considered an addition or alternative to art programs offered in public or private schools. The purpose of the community art programs is to provide children with additional or unique opportunities to experience art making. These programs often attempt to meet the social needs of the children. Community art programs often emerge because art programs in public and private schools are either under-funded or non-existent.

What is community art education? The dictionary defines community as a unified body of individuals; people with common interest living in a particular area, the "community." In many definitions community refers to a location where people of common interest and characteristics live together. Another definition indicates joint ownership or participation. When we place the word art education next to community to create the phrase "community art education", what are we talking about?

This phenomenon is generally defined as a collaborative creative process between a professional practicing artist and a community or a process of collaboration between artists and community in addressing agreed upon issues as expression of identity, relationship, or purpose. It is important as a community development process, as a means to connect artists with the community, to encourage participation in the arts, and to demonstrate the relevance of the arts to every day life. All of these definitions express the idea of an artist being in the center of the mix. However, other definitions place more focus on participation in the art making. One such definition indicates that community art education is art-making characterized by the active participation of people sharing in the creative process, thereby making their own art. While these definitions provide an interesting perspective, when we look at traditions coming out of Africa, we find that art served and was an integral part of the community and consequently was something slightly different from the concept of community art in the Western world.

In the African context a community was more about a location where in some cases individuals were connected in some 
way by bloodline or marriage and in other cases where individuals were connected by occupation. And when community is coupled with the expression art education, the definition focuses more on a community's active intervention in its own cultural development and future. This definition brings to bear the purpose of art in the community, in short, how the community created and used art to intervene in the peoples' or community's cultural and social wellbeing. This notion is not just reserved for the traditional context of African art it also embraces the contemporary context of art in many African rural and urban communities. In this paper I will explore this notion of active intervention of art in ones own cultural development by looking briefly at some traditional African examples and then more specifically at a phenomenon called set-setal, a movement that took place in Senegal between the years of 1989 and 1992. The term set-setal is Wolof word that means cleanse. Set means 'clean' and setal means 'to make clean.' The redundancy of the expression, clean and clean, reflects to concerns with physical and morale cleanliness. What makes this contemporary phenomenon so interesting is that issues of physical and morale cleanliness have always been at the center of the use of art in traditional African communities.

\section{Traditional african cultures}

Many Africa cultures have always had art that actively intervened in the cultural development and future of a community. In these cases, art objects were used for social control, to maintain social standards, reinforce historical concepts, educate the youth, and insure a peaceful existence. Sometimes that intervention was facilitated by a mask, a statue or other aesthetic objects. In some societies, masquerade dances, for example, were performed to cleanse the community of unwanted negative forces. In other societies objects were created to educate and socialize people to values and concepts important to the community. In this way, traditional African art was an integral part in the lives and communities of many African peoples. For example, the Kwele people of Gabon, Congo, and Cameroon 
believed that unexplained deaths, epidemic smallpox and other mysterious treats to the well being of the community were caused by witchcraft. The antidote to witchcraft was the beete ritual, which included the performance of the Eluk mask (CHANDA, 1993). The ceremony took place a regular intervals but was mainly enacted when serious events tool place such as illness of a dignitary, a fruitless hunt, attack on the village, etc. The word Eluk refers to protective forest spirits. The purpose of the mask was to unite the community in harmonious interaction against negative forces.

The Kwele masks were carved in many styles but all usually similar basic characteristics, painted white heart-shpaed faces created with powdered earth pigments, and narrow, slit eyes. The white paint symbolizes light and clarity, two essential weapons in the fight against witchcraft. The color is made from kaolin and derives its magical force from having been stored with powerful skulls of deceased family members preserved in reliquaries. These skulls were kept in baskets, which were decorated with "carved wooden heads" and were placed in the living hut behind the bed of the head of the family (DESCHAMPS, 1962). By being this close, the ancestors could advise the head of the family in his dreams and reveal the future. This power was mobilized against the negative forces of witchcraft, which could destroy the health and harmony of a village.

Many art objects in the context of traditional African were mnemonic devices, objects used to assist individuals in recalling or remembering ideas, concepts and history. For example, the Luba used the Lukasa as a memory aid. In this $18^{\text {th }}$ or $19^{\text {th }}$ century object, the patterns created by beads and pins on the surface, along with the ridges and depressions recall important mythical or historical events. These patterns, ridges, and depressions act as ideograms that are read. The reading depends on the occasion in which the device is being used. The 'reading' of the device is public. This device is like a text that registers knowledge, documents history, ideology and culture (BIEBUYCK \& HERREMAN, 1999). Those who read the lukasa are apart of the Mbudye association. They are rigorously trained and are known as the 'men of memory.' The 'men of memory' learn the 
various referential iconography. Knowledge of this iconography stimulates their memory. For example, the

colored beads refer to specific culture heroes and the principal protagonists of Luba myth. Lines of beads refer to journeys, roads, and migrations. A large bead surrounded by a circle of smaller ones refers to a chief encircled by his dignitaries. The iron pin refers to the king in whose honor the board is made, and the incised patterns encode royal secrets. (BIEBUYCK \& HERREMAN p. 285).

The board is divided into two parts, one representing the male aspects and the other the female. This division permits the reading of genealogies.

In addition to using objects for social control and history, African cultures have a long tradition of using art objects as educational tools. These tools were generally made manifest during initiation cycles or community activities related to funerals or social entertainment. The Pende of the Democratic Republic of the Congo, for instance, produced a fine wooden mask that is half black and half white with distorted features that refer to disease or facial paralysis. The mask demonstrates how even the most esteemed and upright member of the community, such as a hunter, can unexpectedly be afflicted with sickness brought on by sorcery, if he has moral flaws. Thus the intent of the mask is to teach Pende audiences about the rewards of good behavior and of the pitfalls of those who are morally flawed. Traditionally, the mask participated in the mbuya masquerade, which was part of initiation ceremonies for boys. Now they are predominately used to entertain foreign visitors. But they also appear when a new chief is appointed, during construction if a chief's house and at the end of the farming season (PERANI \& SMITH, 1998). The black and white faced mask is known as the clown mask whose purpose is to call established values into question. According to Perani and Smith (1998, p. 271), in the entertainment context, the clown-mask makes comments about and critiques "the socio economic changes brought about by colonialism and independence". 


\section{From the rural to the urban}

At first glance one might assume that this process of community art serving as objects of cultural development and continuity has been eroded by the birth and development of urban areas throughout Africa. However, art continues to be used as a tool for commenting on and critiquing socio economic changes related to colonialism and independence in both the rural and urban areas. There are, however, distinctive differences in how the community might be defined. As indicated earlier, community in the rural sense was based on individuals who were related by blood or occupation. Urban areas unlike most rural areas are defined by heterogeneous groups of people from diverse ethnic groups and geographical locations. The community as it existed in the traditional sense, is no longer a viable option in an urban environment. People coming from diverse rural areas converge onto the big cities looking for better ways of life, jobs, education etc. Unfortunately, they find alienation. According to Diouf (2001) the urban city are filled mostly with the youth, those born after independence. As indicated earlier, they come looking for better opportunities, but find alienation and marginalization, for they do not fit in the new culture of the urban environment.

A heterogeneous community generally does not seem like a likely space for a collective discourse since according to Repetti (2001, p. 11). "forced proximity of heterogeneous cultural groups encourages the fragmentation of the mbookk (the polygamous extended family), and the weakening of its supportive functions, and imposes a modification of the social traditional relationships". However, in Senegal youth, (pupils, students, and jobless young people) came together in the late 80 s and created a social movement called 'set-setal.' Some say the movement was triggered by the syncopated beat of world music superstar Youssou N'Dour who wrote and sang songs about cleanliness, dignity, and rectitude (ROBERTS \& ROBERTS, 2002). The song came out at a time when there were "tensions between urban youth and the Senegalese government over a lack of jobs and the collapse of basic city services" (ROBERTS \& ROBERTS, 2002, p. 58). These marginalized youth, however, 
did not take to the streets to riot, but instead tried to reclaim public spaces by beautifying them by collecting trash and painting walls with icons of popular culture and Sufi ${ }^{1}$ saints. On the one hand the intent of this movement was as the Wolof word 'set' would indicate to clean, the streets, reclaim, repaint, replace colonial monuments, and rename alienated spaces. On the other hand the intent of this movement was to break with historical discourse, which had been perpetuated by the nationalist generation (DIOUF, 1992).

To help the marginalized youth find their place in heterogeneous communities or 'quartiers' (French), numerous associative organizations, such as mutual-aid societies and Islamic associations provided help and created a space of mutual support and assistance through discourse, practical co-operation, and mutual solidarity. These associations bind people with ties that are connected to family, ethnic groups, religion or business (REPETTI, 2001). Not only were these 'quartiers' bound by social elements but also their own idiosyncratic memories, which added to the various social identities that provided a sense of belonging for the Senegalese youth. The cohesive element that connects the members of these 'quartiers' are the stories the community generates. These stories form a communal awareness. According to Repetti (2001, p. 2), the "shared accumulation of oral traditions based on the district is spread among the residents and is virtually unknown outside the borders of the district". These stories provide the impetus for renaming alienated spaces. One district or quartier, for example, changed its name from HLM 6 to HLM 'angle Mouss' or 'corner cat' because of a story about a cat entering a house and changing into a witch. Nomenclatures such as this one or "angle ngoumba" (corner of the blind), or 'Patte d'oi' (Webbed foot of the goose) replace the official designated names of HLM zones indicated by numbers (HLM1, HLM 2 etc.) (REPETTI, 2001). According to Repetti (2001), this "identity discourse through fellowship" represents the social foundation of the urban artistic production which was the hallmark of the set-setal movement.

While it would appear from the literature that the youth simply decided to undertake this activity without assistance 
from the government entities, in actuality according to Repetti (2001, p. 9) the "Municipalité of Dakar assigned the implementation of the Set-Setal: ...to associations and local artists. The decorative campaign of social education was given subsidies to decorate town areas with murals".

The Set-Setal movement of the late 80s involved thousands of Senegalese youth who were mobilized to cleanup local sites where trash and rubbish signified the negligence of the Dakar government. In an effort to clean they were also fighting against corruption, prostitution, and delinquency brought on by an inefficient government. The murals, while falling into three main themes, sanitation, ecology, and history, can be classified as educational tools designed to institute some for of social control. They also in the context of some specific communities act as devices that create or recreate history. The ones dealing with sanitation focus on issues related to HIV/AIDs, vaccinations, and the struggle against diarrhea. Most of these are accompanied by a text to clarify the educational messages. For example, the one on diarrhea indicates "Comment on attrappe la Diarrhee". This is how one catches diarrhea. The image in a narrative form indicates that if children defecate and play in the same area they will get diarrhea. A large number of children each year die from contracting diarrhea, thus the campaign to inform citizens becomes crucial.

Concerns for the ecology can be found in this example, which says "ne couper pas les arbres", don't cut down the trees. Africa is facing grave issues of deforestation. As loggers and farmers clear land for agriculture, vegetation cover is removed, and areas are exposed to erosion and the washing out of minerals and nutrients, leaving a poor soil. In West African this is most acute where over $90 \%$ of the forest has been lost. In addition, to the loose of minerals and nutrients, deforestation causes climate changes.

In the historical theme approximately $11.7 \%$ are religious in nature while the others make political references (DIOUF, 1992). The ones that give reference to politics are more international than local, but they draw not on colonial historic figures, but those that seem to have more relevance to the youth of 
today. These murals feature international political figures such as Nelson Mandela, Malcom X, and Ché Guevara. Other political statements are made through the symbolic representation of sénégambien fables that feature the fox and the rabbit and the goat and the hyena. In one mural the goat and the hyena antagonists in traditional fables become friends playing soccer with the lion, a symbol of peace (REPETTI, 2001). The religious ones focus for the most part on the representation of Ahmadou Bamba a marabout holy man who became a saint. He was born in 1853 and had a Sufi affiliation ${ }^{2}$. He was a pacifist who carried a pen, not a gun. He obtained sainthood by performing miracles such as praying on the waters, calming a ravenous lion, and escaping the cruel plots of his French captors. Images of Bamba dominate the 'quartiers' that are predominately Muslim. These murals not only serve to decorate or beautify the city they tell of the history and power of Bamba, for Mourides ${ }^{3}$ touch Bamba's image to their foreheads or kiss wall murals to receive his blessing" (ROBERTS \& ROBERTS, 2002, p. 55). Where normally imagery of humans in Islam is forbidden, in this context the visual image is used as apparatus of intercession.

A key player in the creation of murals connected with the Set-Setal movement was a young graffitist named Pape Samb. His more popular name is Papisto Boy. He arrived in Dakar some years ago as a ten-year-old orphan. He has lived in a fishing community that is squeezed between factory yards and an industrial park called Belaire. The artist paints murals as a devotional task to the Mouride Way. He is a self-taught artist and is most noted for his mural that stretches more than six hundred feet along the outer walls of the factory in Belaire. This mural contains portraits of Nelson Mandela, Jimi Hendrix, Malcom $X$, and others. He says his inspiration comes from dreams and his hand is guided by the saint. Outside of Amadu Bamba Bob Marley is the image that appears most often. Bob Marley is considered a 'messenger' who passed through music to inspire Papisto. Unlike the other murals inspired by the Set-Setal movement Papisto Boy has been working on his mural on the dingy factory walls for 30 years and thus his work is always a work in progress. It has paintings over paintings that do not completely 
obscure the other ones. Sometimes he sees something hidden in a portrait or scene that he then paints. The portrait of Ché Guevara is a perfect example of this. One morning as he stood gazing at the face of the opposition politician Abdoulaye Wade a portrait of Ché Guevara revealed itself and Papisto Boy painted it.

\section{Conclusion}

As we have seen, art in African societies continues to be used to exert social control, maintain social standards, reinforce historical concepts, and educate the populace. Where in the past its use focused on controlling unpredictable forces, in the context of Senegal's contemporary urban setting it is being used to transform marginalized spaces into 'imagined spaces' created out of a desire to control an environment that had been neglected by the government of Dakar. This control took the form of murals that recreated history, produced shared memories, and educated the community on social issues. Unfortunately, unlike the traditional art objects whose use and function was reinforced by the collective homogeneous community, these murals have an ephemeral nature and are fragile to time and pollution and according to some have already began to fade away.

\section{Notes}

1. Sufi is a Muslim who represents the mystical dimension of Islam; a Muslim who seeks direct experience of Allan.

2. Sufism arrived at its present form in the seventh century A.D. "The Way of Love," as the religion is called, is a path designed to facilitate the direct personal union of human beings with the "Divine Beloved." Through this union, the seeker, strengthened by discipline and grace, is led to experience the essence of divine love and wisdom in the world, and to attain consciousness of the "One Reality."

3. Mourides are followers of Mouridism a contemporary Islamic movement inspired by the Seneglese Sufi pacifist, poet and saint Amadou Bamba. 


\section{References}

BIEBUYCK, D \& HERREMAN, F. Central Africa in Philips, T. ed. Africa: The art of a continent. New York: Prestel, 1999.

CHANDA, J. African art and culture. Davis: Worcester, Massachusetts, 1993.

DESCHAMPS, H. Traditions et archives au Gabon. Paris: Berger-Levrault, 1962.

DIOUF, M. Citoyennetes et recompositions identitaires dans les villes ouest Africaines (Citizens and recomposition of identify in West African cities), Sahel 21, 2001.

DIOUF, M. Fresques murales et écriture del'histoire: Le Set/Setal à Dakar. Politique Africaine 46, 41-54, 1992.

PERANI, J. \& Smith, F. The visual arts of Africa: gender, power, and life cycle rituals. New Jersey: Prentice Hall, 1998.

REPETTI, M. Marking Dakar: A topography of imaginary. Spring, Translated Deidre Kantz Xcp: Streetnotes, www.xcp.bfn.org/call4work.html, 2001.

ROBERTS, A. \& ROBERTS, M. A Saint in the city: Sufi arts of urban Senegal. African Art, 35(4) 52-73, 2002.

ROBERTS, A. \& ROBERTS, M. Papisto Boy. African art, 32(2) 72-79, 2000.

\section{JACQUELINE CHANDA}

is Professor of Art Education and Art History at the University of North Texas. E-mail: chanda@unt.edu. 